\title{
Invasion of Vero cells by Salmonella species
}

\author{
P. A. BARROW and M. A. LOVELL
}

Department of Microbiology, AFRC Institute for Animal Health, Houghton Laboratory, Houghton, Huntingdon, Cambridgeshire PE17 2DA

\begin{abstract}
Summary. The invasiveness of Salmonella strains for Vero cells was studied by quantitative bacteriology; the technique was more sensitive than phase contrast microscopy. All of 59 Salmonella strains, of 19 different serotypes, were more invasive than Escherichia coli K12. Three strains of Shigella were as invasive as most of the Salmonella strains whereas 29 strains of E. coli, two of Proteus, three of Klebsiella and one of Serratia were much less invasive. Two Citrobacter strains exhibited intermediate invasiveness. Eleven Salmonella strains were also shown to be invasive in HeLa, int 407, bovine kidney, chick kidney and chick embryonic fibroblast cells. The difference between invasive and non-invasive organisms was apparent irrespective of the numbers of bacteria in contact with Vero cells or the duration of bacteria-cell contact. There was little intracellular multiplication of $S$. typhimurium in Vero cells. Unlike the situation with Shigella, incubation of Salmonella or Salmonella-cell mixtures at $41^{\circ} \mathrm{C}, 22^{\circ} \mathrm{C}$ or $0^{\circ} \mathrm{C}$ had little effect on invasiveness. Non-viable Salmonella organisms were non-invasive. Incubation of Vero cells with cholera toxin, dinitrophenol, iodoacetic acid, cytochalasin B or D-mannose did not substantially reduce invasiveness. Virulence-associated plasmids were not essential to invasion by $S$. typhimurium, $S$. gallinarum or $S$. pullorum. Neither somatic antigens nor mannose-sensitive haemagglutinins were essential to the invasiveness of an $S$. infantis strain, but an additional factor, eliminated by $N$-methyl, $N$-nitro, $N$-nitrosoguanidine mutagenesis did contribute to invasiveness.
\end{abstract}

\section{Introduction}

Salmonella spp. are normally transmitted by the faecal-oral route (Buxton, 1957) and the importance of invasion via the alimentary tract to the virulence of serotypes that characteristically produce systemic disease, such as $S$. typhi, S. dublin, S. choleraesuis, $S$. gallinarum and $S$. abortus-equi, is self evident. In some cases invasiveness has been demonstrated experimentally (Smith, 1955; Smith and Jones, 1967; Smith and Halls, 1968; Tannock et al., 1975). Invasiveness of $S$. typhimurium, which typically produces severe systemic disease in young animals, has also been demonstrated in newly-hatched chickens (Barrow et al., 1987a) and in calves (Clarke and Gyles, 1985). Similarly, the passage of $S$. enteritidis and $S$. thompson through and between intestinal mucosal cells, as the first stage of systemic infection of newly-hatched chickens, has been demonstrated by electronmicroscopy (Turnbull and Richmond, 1978; Popiel and Turnbull, 1985).

Most other serotypes are usually associated only with human gastroenteritis (food poisoning). $\mathrm{Mu}$ -

Received 17 May 1988; accepted 11 July 1988. cosal invasion can be demonstrated microscopically in natural and experimental cases of gastroenteritis produced by $S$. typhimurium in man (Day et al., 1978) and rhesus monkeys (Kent et al., 1966; Giannella, 1975). The extent to which invasiveness is involved in colonisation of the alimentary tract in animals in the absence of disease is unknown but invasive serotypes may be shed in chicken faeces for shorter periods than non-invasive strains (Barrow et al., 1988).

Understanding of the basis of invasiveness of another enteric pathogenic genus, Shigella, has increased considerably by use of tissue culture to study invasion in vitro (Sansonetti et al., 1982, 1983, 1986; Hale et al., 1983; Watanabe and Timmis, 1984; Watanabe and Nakamura, 1986). In contrast, knowledge of the interactions between Salmonella spp. and non-phagocytic cells is fragmentary. Invasion of $\mathrm{HeLa}$ and $\mathrm{HEp}-2$ cells by $S$. typhimurium has been demonstrated in vitro (Giannella et al., 1973; Kihlstrom and Edebo, 1976; Kihlstrom and Latkovic, 1978; Jones et al., 1981; Small et al., 1987). However, little is known of the microbial determinants and cell receptors involved, or how these relate to host specificity. 
Irreversible attachment to $\mathrm{HeLa}$ cells is a prerequisite to invasion by $S$. typhimurium (Jones $e t$ al., 1981). Production of a mannose-resistant haemagglutinating adhesin, involved in the pre-invasion attachment stage, was thought to be reduced by culture at low temperatures (Jones and Richardson, 1981) as occurs with Shigella spp. (Maurelli et al., 1984), but later work has not confirmed this (Small et al., 1987). Jones et al. (1982) suggested that adhesion to, and invasion of, HeLa cells was mediated by the $85-\mathrm{kb}$ virulence-associated plasmid found in this serotype. However, this finding also has not been confirmed (Pardon et al., 1986; Gulig and Curtiss, 1987). Kihlstrom and Edebo (1976) found that "rough" cell wall mutants were more invasive, since these showed increased hydrophobicity and attached to cells in greater numbers. Unlike Sh. flexneri, S. typhimurium does not multiply rapidly intracellularly (Devenish and Schiemann, 1981 ; Sansonetti et al., 1986; Small et al., 1987).

The above studies have generally been limited to $S$. typhimurium. We have compared invasion of several different cell types by various Salmonella spp. and have selected one for further study of the kinetics of invasion and of the microbial determinants that might be involved.

\section{Materials and methods}

\section{Bactẹrial strains}

Strains of S. typhimurium, S. anatum, S. enteritidis, $S$. givé, $S$. hadar, $S$. heidelberg, $S$. indiana, $S$. infantis, $S$. kedougou, S. kentucky, S. ohio, S. oranienburg, S. presov and $S$. virchow were isolated from cases of human food poisoning or from the alimentary tract of healthy chickens. Additional strains of S. typhimurium and strains of $S$. gallinarum, $S$. pullorum, $S$. dublin, $S$. cholerae-suis, $S$. abortus-ovis and $S$. abortus-equi were isolated from cases of systemic animal salmonellosis. Shigella strains were originally isolated from cases of human dysentery. Escherichia coli strains obtained from the culture collection at this laboratory were originally isolated from healthy pigs and calves and cases of porcine bowel oedema, calf and chicken septicaemia, bovine mastitis and diarrhoea in pigs, calves and man. Citrobacter, Klebsiella, Proteus and Serratia strains were isolated from the alimentary tract of various species.

All bacterial strains were maintained on Dorset's egg slopes at $4^{\circ} \mathrm{C}$. Broth cultures were made in 10 -ml volumes of Nutrient Broth (Oxoid, CM67), incubated at $37^{\circ} \mathrm{C}$ for $24 \mathrm{~h}$ in a water bath with shaking. Such cultures usually contained between $8 \times 10^{8}$ and $2 \times 10^{9} \mathrm{cfu} / \mathrm{ml}$.

Full details of the production of mutants of $S$. typhimurium strain F98, $S$. infantis strain 1326/28, $S$. gallinarum strain 9 and $S$. pullorum strain 3 were described by Barrow et al. (1988). Non-flagellate mutants of the $S$. typhimurium and $S$. infantis strains and a mannosesensitive non-haemagglutinating mutant of the $S$. infantis strain were obtained by $N$-methyl, $N$-nitro, $N$-nitrosoguanidine (NTG) mutagenesis as described by Barrow $e t$ al. (1988).

"Rough" cell-wall mutants of $S$. typhimurium, $S$. gallinarum and $S$. pullorum were prepared as follows: bacteriophages, lytic for each strain, were isolated from sewage (Barrow, 1986). Plates of Tryptose Agar (Difco) were flooded with equal volumes of broth cultures of the bacteria and a dilution of phage which would just produce confluent lysis. Rough mutants were selected by their granular consistency or by one of the following characteristics: non-agglutination with appropriate O-antiserum (Wellcome Diagnostics), spontaneous agglutination in physiological saline, or agglutination by acriflavine $0.2 \%$ (Smith, 1965).

The $85-\mathrm{kb}$ virulence plasmids of the $S$. gallinarum and $S$. pullorum strains were cured by methods described previously (Barrow et al., 1987b; Barrow and Lovell, 1988). The plasmid carrying transposon 3 (pSC101::Tn3), which was used to "tag" the virulence plasmid of $S$. typhimurium F98, was introduced by mobilisation with the I plasmid in a prototrophic strain of $E$. coli $\mathrm{K} 12$. The tagged virulence plasmid was eliminated by incubation at $42^{\circ} \mathrm{C}$ for $18 \mathrm{~h}$ as used for $S$. gallinarum 9 (Barrow et al., 1987b).

\section{Cell culture}

All cells were grown as monolayers at $37^{\circ} \mathrm{C}$ in a $\mathrm{CO}_{2}$ incubator. Vero, $\mathrm{HeLa}$, human intestine 407 and bovine kidney cell lines were obtained from Flow Laboratories. Vero cells were grown in 199 medium (Flow) containing fetal calf serum $10 \%$ and L-glutamine $1 \%$. HeLa and bovine kidney cells were cultured in Eagle's minimal essential medium containing fetal calf serum $10 \%$, glutamine $1 \%$ and non-essential amino acids $1 \%$. Intestine 407 cells were cultured in Eagle's medium containing Hanks's Balanced Salts Solution (HBSS), calf serum 15\% and glutamine $1 \%$.

Primary chicken kidney cells were prepared from the kidneys of 2-3 weeks old chickens. Kidneys were removed aseptically, teased and trypsinised with Versene $(\mathrm{NaCl}$ $0.8 \%, \mathrm{KH}_{2} \mathrm{PO}_{4} 0.02 \%, \mathrm{KCl} 0.02 \%, \mathrm{Na}_{2} \mathrm{HPO}_{4} \quad 0.15 \%$, EDTA $0.02 \%$ ). The cells obtained were cultured in 199 medium containing Tryptose Phosphate Broth (Difco) $10 \%, \mathrm{NaHCO}_{3} 0.8 \%$, calf serum $8 \%$, amphotericin $\mathrm{B}$ $0.04 \%$ and gentamicin sulphate $0.001 \%$.

Primary chicken embryo fibroblasts were prepared from 10-day-old embryonated eggs. The embryo was decapitated, eviscerated and macerated. The macerate was washed and trypsinised. Cells thus obtained were cultured in a medium similar to that used for chicken kidney cells, but without amphotericin B or gentamicin.

\section{Invasion of cells}

The method was similar to that of Peerbooms et al. $(1984,1985)$. Briefly, bacterial cultures were diluted in 
modified HBSS. For most organisms a 1 in 200 dilution was used. However, for strains such as $S$. gallinarum, $S$. pullorum, $S$. abortus-equi and $S$. abortus-ovis which did not grow well in broth, and for cultures grown at lower temperatures, the dilutions were reduced so that the inoculum was similar to that of the control. Monolayers of cultured cells, in 24-well "Linbro" plates (Flow Laboratories), were washed twice in HBSS and were then incubated with the bacterial suspension for $2 \mathrm{~h}$ at $37^{\circ} \mathrm{C}$ in air. At this point the number of viable bacteria $/ \mathrm{ml}$ of suspension in contact with the cells was courited. The monolayer was washed once in HBSS and subsequently incubated for $1.5 \mathrm{~h}$ at $37^{\circ} \mathrm{C}$ in 199 medium containing kanamycin $250 \mu \mathrm{g} / \mathrm{ml}$ to kill extracellular bacteria (Okamura et al., 1983). The cells were then washed twice with HBSS and lysed for $30 \mathrm{~min}$ at $37^{\circ} \mathrm{C}$ with trypsin $0.025 \%$ and Tween $201 \%$ in $0.01 \mathrm{M} \mathrm{NaH} \mathrm{NO}_{4}$ at $\mathrm{pH} 8$. Intracellular and extracellular bacteria were counted on nutrient-agar plates.

In all experiments, invasive ( $S$. typhimurium F98) and non-invasive ( $E$. coli $\mathrm{K} 12$, prototrophic) control strains were included.

For phase contrast microscopy fragments of sterile glass coverslips were laid on the base of the wells before cell culture. Suspensions of bacteria were incubated with the cells in the usual way but immediately before lysis the coverslips were removed for observation.

\section{Effect of cytochalasin B, metabolic inhibitors and cholera toxin}

Cytochalasin B (Sigma), dissolved in dimethyl sulphoxide, and two metabolic inhibitors, 2, 4-dinitrophenol and iodoacetic acid (Sigma), were incorporated in the modified HBSS medium at the desired concentrations for the 2 -h period of incubation with bacteria. Cholera toxin
(Sigma), diluted in modified HBSS, was incubated with Vero cells for $3 \mathrm{~h}$ before and for the $2-\mathrm{h}$ duration of incubation with bacteria.

\section{Sensitivity to kanamycin}

Selected strains were tested for their sensitivity to kanamycin. Doubling dilutions of kanamycin in the range $500-1.0 \mu \mathrm{g} / \mathrm{ml}$ were prepared in Sensitivity Test Agar (Oxoid CM409). Plates were inoculated with $0.02 \mathrm{ml}$ of a dilution of each strain, containing $c .10^{4} \mathrm{cfu} / \mathrm{ml}$. Minimum inhibitory concentration (MIC) values were calculated after overnight incubation at $37^{\circ} \mathrm{C}$.

\section{Results}

\section{Validation of the method}

The invasiveness of selected organisms for Vero cells, as assessed by quantitative bacteriology and by phase-contrast microscopy, is shown in table I. The quantitative bacteriological invasion test was replicated five times for $S$. infantis and ten or more times for the other strains. S. typhimurium, $S$. infantis and Sh.flexneri were the most invasive, the numbers of organisms $/ \mathrm{ml}$ of lysate being between $0.1 \%$ and $1 \%$ of the inoculum of $c .10^{7} \mathrm{cfu} / \mathrm{ml} . S$. gallinarum and $S$. pullorum exhibited intermediate invasiveness and the $E$. coli $\mathrm{K} 12$ strain was virtually non-invasive. For all six strains the standard errors were small, suggesting that the method was reproducible. Because of this, subsequent results are presented as the mean values from two separate wells examined simultaneously.

Table I. Invasiveness of Salmonella spp. Sh. flexneri and E. coli K 12 for Vero cells

\begin{tabular}{|c|c|c|c|}
\hline \multirow[b]{2}{*}{ Bacterial strain $(n)^{*}$} & \multicolumn{2}{|c|}{$\log _{10} \mathrm{cfu} / \mathrm{ml}$ and standard error (range) in } & \multirow{2}{*}{$\begin{array}{c}\text { Invasiveness by } \\
\text { phase contrast } \\
\text { microscopy }\end{array}$} \\
\hline & $\begin{array}{l}\text { suspension added to } \\
\text { Vero cells }\end{array}$ & Vero-cell lysate & \\
\hline $\begin{array}{l}\text { S. typhimurium F98 } \\
\text { (17) }\end{array}$ & $\begin{array}{l}7 \cdot 3 \pm 0 \cdot 4 \\
(6 \cdot 8-7 \cdot 7)\end{array}$ & $\begin{array}{l}4 \cdot 9 \pm 0 \cdot 4 \\
(4 \cdot 6-5 \cdot 2)\end{array}$ & + \\
\hline $\begin{array}{l}\text { S. infantis } 1326 / 28 \\
(5)\end{array}$ & $\begin{array}{l}7 \cdot 6 \pm 0 \cdot 2 \\
(7 \cdot 3-7 \cdot 9)\end{array}$ & $\begin{array}{l}4 \cdot 6 \pm 0 \cdot 2 \\
(4 \cdot 4-4 \cdot 9)\end{array}$ & + \\
\hline $\begin{array}{l}\text { Sh. flexneri } 59 \\
\text { (11) }\end{array}$ & $\begin{array}{l}6 \cdot 9 \pm 0 \cdot 1 \\
(6 \cdot 8-7 \cdot 1)\end{array}$ & $\begin{array}{l}4 \cdot 2 \pm 0 \cdot 2 \\
(3 \cdot 8-4 \cdot 6)\end{array}$ & + \\
\hline $\begin{array}{l}\text { S. gallinarum } 9 \\
\text { (11) }\end{array}$ & $\begin{array}{l}6 \cdot 9 \pm 0 \cdot 1 \\
(6 \cdot 8-6 \cdot 9)\end{array}$ & $\begin{array}{l}3 \cdot 3 \pm 0 \cdot 1 \\
(3 \cdot 0-3 \cdot 6)\end{array}$ & - \\
\hline $\begin{array}{l}\text { S. pullorum } 3 \\
(10)\end{array}$ & $\begin{array}{l}7 \cdot 0 \pm 0 \cdot 1 \\
(6 \cdot 9-7 \cdot 1)\end{array}$ & $\begin{array}{l}2 \cdot 5+0 \cdot 1 \\
(2 \cdot 3-2 \cdot 9)\end{array}$ & - \\
\hline $\begin{array}{c}\text { E. coli } \mathrm{K} 12 \\
(17)\end{array}$ & $\begin{array}{l}7 \cdot 0 \pm 0 \cdot 2 \\
(6 \cdot 7-7 \cdot 3)\end{array}$ & $\begin{array}{l}0.8 \pm 0.5 \\
(<1.0-1.8)\end{array}$ & - \\
\hline
\end{tabular}

$* n=$ Number of times test was replicated. 
Ten selected Salmonella strains, Sh. flexneri and $E$. coli $\mathrm{K} 12$ were retested by quantitative bacteriology for invasiveness in HeLa, human intestine 407, bovine kidney, chicken kidney and chick embryo fibroblast cells. Results were very similar to those described for Vero cells; $S$. gallinarum and $S$. pullorum were no more invasive in chicken cell types than they were in cells of mammalian origin. Because of these results all further work was carried out on Vero cells only.

To show that differences in invasiveness were not the results of differences in susceptibility to kanamycin, MICs of kanamycin for selected invasive and non-invasive strains were calculated. MICs of kanamycin for invasive Salmonella strains, $S h$. flexneri 59, S. gallinarum 9, S. pullorum 3, one Citrobacter strain, five "wild" strains of $E$. coli and $E$. coli $\mathrm{K} 12$ were in the range $\leqslant 1-4 \mu \mathrm{g} / \mathrm{ml}$. The MIC of kanamycin for $E$. coli $\mathrm{K} 12$ carrying plasmid pML21, encoding kanamycin resistance, was $>500 \mu \mathrm{g} / \mathrm{ml}$.

Viable counts obtained from Vero-cell lysates, estimated after carrying out an invasion test with the kanamycin-resistant and -sensitive strains of $E$. coli $\mathrm{K} 12, S$. typhimurium $\mathrm{F} 98$ and $S$. gallinarum, were $\left(\log _{10}\right.$ cfu) $6.4,1 \cdot 8,4 \cdot 2$ and 3.1 respectively.

By phase contrast microscopy $\leqslant 1 \%$ of Vero cells appeared to be infected by $S$. typhimurium, $S$. infantis or Sh. flexneri. Invasive bacteria, sometimes several together, were present in intracellular vacuoles; the Salmonella strains were easily distinguishable by their motility. In the case of $S$. gallinarum, $S$. pullorum and $E$. coli K 12 no intracellular organisms were visible.

Similarly, cells of $S$. typhimurium F98 that had been killed by formaldehyde, ethanol, chloroform or by heating at $58^{\circ} \mathrm{C}$ for $30 \mathrm{~min}$ appeared noninvasive.

\section{Invasiveness of Salmonella and other genera}

The invasiveness of 20 Salmonella serotypes and of other members of the Enterobacteriaceae for Vero cells is shown in table II. Of the genera tested Salmonella was the most invasive. The highest viable count obtained from the Vero-cell lysate, $\left(10^{6 \cdot 1} \mathrm{cfu}\right)$, was obtained with one strain of $S$. typhimurium, and many strains of $S$. typhimurium, $S$. dublin, $S$. cholerae-suis and various food-poisoning serotypes produced lysate counts of $>10^{5} \mathrm{cfu}$. $S$. gallinarum, $S$. pullorum, $S$. abortus-equi and $S$. abortus-ovis exhibited intermediate invasiveness.

Of the other genera tested, Shigella was most invasive. Several strains of $E$. coli and two Citrobacter strains were more invasive than $E$. coli $\mathrm{K} 12$.
Table II. Invasiveness of Salmonella and other genera for Vero cells

Species tested ( $\mathrm{n})$ $\log _{10} \mathrm{cfu} / \mathrm{ml}$ of Vero-cell lysate

\begin{tabular}{|c|c|}
\hline S. typhimurium (29) & $5 \cdot 3(4 \cdot 5-6 \cdot 1)^{*}$ \\
\hline S. gallinarum (2) & $2 \cdot 6,3 \cdot 3$ \\
\hline S. pullorum (1) & $2 \cdot 5$ \\
\hline S. dublin (3) & $5 \cdot 4,5 \cdot 5,6 \cdot 0$ \\
\hline S. cholerae-suis (3) & $4 \cdot 3,5 \cdot 3,5 \cdot 4$ \\
\hline S. abortus-ovis (1) & $3 \cdot 2$ \\
\hline S. abortus-equi (1) & $2 \cdot 5$ \\
\hline S. enteritidis (3) & $4 \cdot 3,4 \cdot 7,4 \cdot 8$ \\
\hline $\begin{array}{l}\text { Salmonella spp. (17) } \\
\text { (12 serotypes) }\end{array}$ & $5 \cdot 1(4 \cdot 5-5 \cdot 4)$ \\
\hline Sh. flexneri (1) & $4 \cdot 2$ \\
\hline Sh. sonnei (1) & $3 \cdot 5$ \\
\hline Sh. dysenteriae (1) & 3.6 \\
\hline E. coli $\mathrm{K} 12(1)$ & 0.8 \\
\hline E. coli $(27) \ddagger$ & $1.9(<1 \cdot 0-2 \cdot 9)$ \\
\hline E. coli $(2) \coprod^{+}$ & $1.9,2.6$ \\
\hline Citrobacter spp. (2) & $3 \cdot 3,2 \cdot 9$ \\
\hline Proteus spp. (2) & $2 \cdot 3,2 \cdot 0$ \\
\hline Klebsiella spp. (3) & $1 \cdot 0,1 \cdot 6,1 \cdot 9$ \\
\hline S. marcescens (1) & 1.0 \\
\hline
\end{tabular}

(n) = Number of strains tested.

* Median count with range in parentheses; for 1-3 strains, all values are given.

$\dagger$ Food-poisoning serotypes $S$. anatum (2), S. givé (1), S. hadar (4), S. heidelberg (1), S. indiana (1), S. infantis (1), S. kedougou (1), S. kentucky (1), S. ohio (1), S. oranienburg (1), S. presov (1), S. virchow (2).

$\$ N$ ine strains from bovine mastitis, 8 enteropathogenic strains from pigs, calves and man, 2 strains from porcine bowel oedema, 3 strains from calf septicaemia and 3 strains from chicken septicaemia.

ๆTwo non-pathogenic porcine strains.

There was no association between the number of $E$. coli recovered from the Vero-cell lysate and the disease or the host of origin. The Proteus, Klebsiella and Serratia strains examined displayed little or no invasiveness.

\section{Kinetics of Vero-cell invasion}

The effect of bacterial numbers on invasion. In experiments in which dilutions of cultures of $S$. typhimurium F98, S. gallinarum 9 and $E$. coli $\mathrm{K} 12$ were incubated with Vero cells, the numbers of bacteria recovered from the Vero cell lysate increased with the inoculum (fig. 1). The differences in invasiveness of the three strains were apparent throughout the range of dilutions. Invasion by the $S$. typhimurium strain was detectable with an inoculum of $c .10^{3} \mathrm{cfu} / \mathrm{ml}$. No further increase in recovery from the cell lysate was observed with any of the strains when the bacterial inoculum was raised from $10^{8}$ to $c .5 \times 10^{8} \mathrm{cfu} / \mathrm{ml}$. 


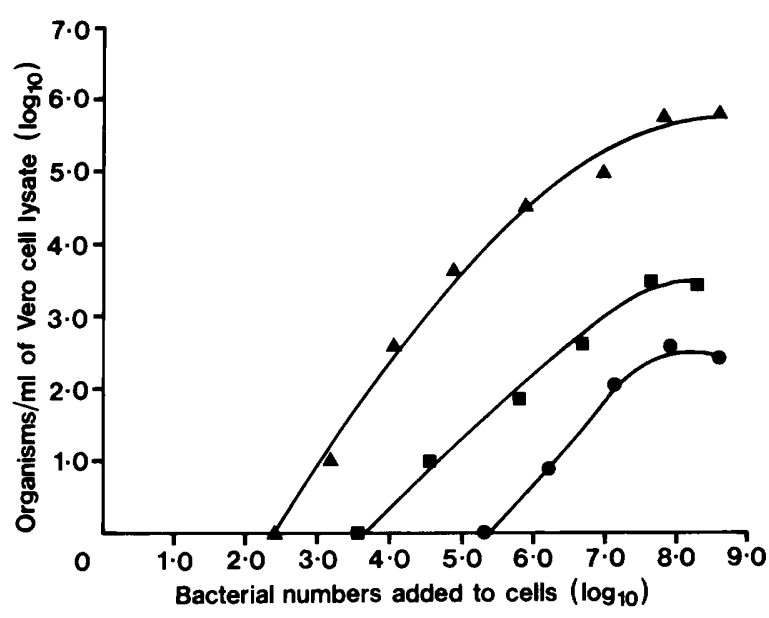

Fig. 1. Recovery of bacteria from Vero-cell lysate after addition of different inocula. Each point represents arithmetic mean of two values. $\triangle S$. typhimurium $\mathrm{F} 98 ; \square S$. gallinarum $9 ; \bigcirc$ E. coli $\mathrm{K} 12$.

The effect of contact time. The recovery of $S$. typhimurium F98 and E. coli $\mathrm{K} 12$ from Vero-cell lysates after contact for varying times is shown in fig. 2. The number of organisms per ml of lysate increased with time, but after $60 \mathrm{~min}$ the rate of increase was small. The number of organisms in contact with the cells remained constant during the course of the experiment. The viable count of $S$. typhimurium in the lysate was always much greater than that of $E$. coli $\mathrm{K} 12$.

Intracellular multiplication of $S$. typhimurium and E. coli K12. After incubation in the presence of

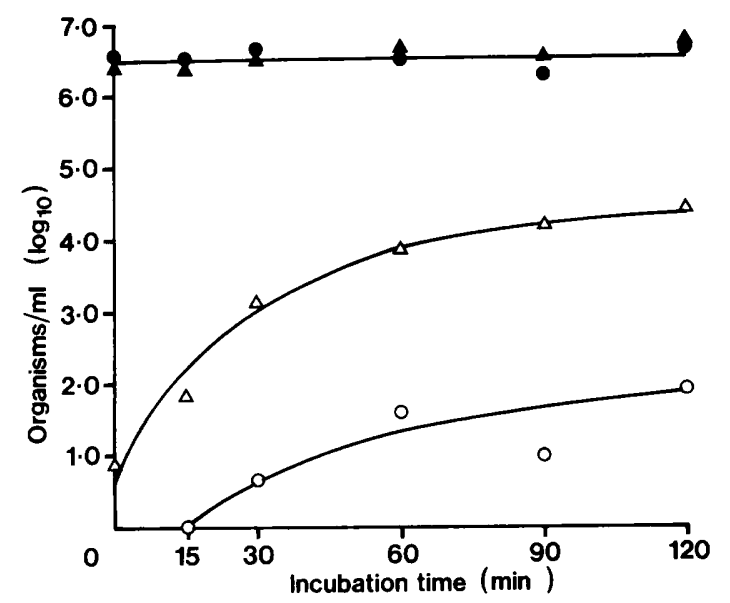

Fig. 2. Recovery of bacteria from Vero-cell lysate as a function of incubation time. Each point represents arithmetic mean of two values. $\Delta$ Number of $S$. typhimurium F98 in contact with Vero cells; number of $E$. coli $\mathrm{K} 12$ in contact with Vero cells; $\triangle$ number of $S$. typhimurium $\mathrm{F} 98$ in cell lysate; $O$ number of $E$. coli $\mathrm{K} 12$ in cell lysate. kanamycin, the number of $S$. typhimurium F98 recovered from cell lysate gradually increased fourfold from $10^{3.9}$ to $10^{4 \cdot 5} \mathrm{cfu}$ at $6 \mathrm{~h}$. On further incubation, the number recovered fell, reaching $10^{4} \mathrm{cfu}$ at $24 \mathrm{~h}$. At this time there was evidence of kanamycin toxicity to the cells, which had started to round up and become detached. With E. coli $\mathrm{K} 12$ the number of bacteria recovered was very low or undetectable throughout the experiment.

The effect of temperature. The ability of $S$. typhimurium, $S$. hadar, $S$. virchow, $S$. heidelberg and Sh. flexneri, cultured at $37^{\circ} \mathrm{C}$ or $22^{\circ} \mathrm{C}$, to invade Vero cells held at $37^{\circ} \mathrm{C}, 22^{\circ} \mathrm{C}$ or $0^{\circ} \mathrm{C}$ during the invasion period was assessed. The final lysis step was carried out at $37^{\circ} \mathrm{C}$ as usual. The results are shown in table III. When bacterial culture and the invasion test were performed at $37^{\circ} \mathrm{C}$ or $22^{\circ} \mathrm{C}$, all strains were fully invasive. When bacteria cultured at $37^{\circ} \mathrm{C}$ were tested for invasiveness at $0^{\circ} \mathrm{C}$ by holding the tissue culture plate on ice in a cold room at $4^{\circ} \mathrm{C}$, the invasiveness of all strains was reduced over 100 -fold. Nevertheless $>10^{3} \mathrm{cfu}$ of salmonellae were recovered per $\mathrm{ml}$ of cell lysate. Salmonella strains cultured at $22^{\circ} \mathrm{C}$ were all fully invasive when tested at $37^{\circ} \mathrm{C}$ or $22^{\circ} \mathrm{C}$. In contrast, the invasiveness of Sh. flexneri cultured at $22^{\circ} \mathrm{C}$ was reduced over 1000 -fold at $37^{\circ} \mathrm{C}$ and almost 100 -fold at $22^{\circ} \mathrm{C}$.

Single strains of $S$. gallinarum, $S$. pullorum, $S$. typhimurium, $S$. cholerae-suis and $E$. coli $\mathrm{K} 12$ cultured at $41^{\circ} \mathrm{C}$ were tested in Vero cells held at $41^{\circ} \mathrm{C}$ to investigate invasiveness at the blood temperature of the chicken. All strains were equally invasive at $41^{\circ} \mathrm{C}$ and $37^{\circ} \mathrm{C}$.

\section{The effect of carbohydrates}

The inclusion of $\mathrm{D}(+)$ mannose $1 \%$ in the bacterial suspension medium had no effect on the invasiveness of eleven strains of Salmonella (10 serotypes). Similarly $D(-)$ arabinose, $D(+)$ raffinose, $N$-acetyl-D-glucosamine, $\mathrm{D}(+)$ galactose and $\alpha$ $D(+)$ fucose (all $1 \%$ ) had no effect on the invasion of two strains of $S$. typhimurium.

\section{The effect of metabolic and phagocytic inhibitors}

The effects of incubating cell-bacteria mixtures with inhibitors of metabolism (2,4-dinitrophenol and iodoacetic acid) and of phagocytosis (cytochalasin B and cholera toxin) are shown in table IV. Dinitrophenol recuced the number of bacteria recovered from the cell lysate by up to $96 \%(S$. typhimurium) and $98 \%$ (Sh.flexneri) of the chemicalfree control counts. However, the number of viable bacteria in contact with the cells also declined. 
Table III. The effect of temperature on Vero cell invasion

\begin{tabular}{|c|c|c|c|c|c|}
\hline \multirow[b]{4}{*}{ Bacterial strain } & \multicolumn{5}{|c|}{$\begin{array}{c}\log _{10} \text { viable count } / \mathrm{ml} \text { of Vero-cell lysate when bacteria or bacteria }+ \text { Vero cell mixture } \\
\text { were incubated at the following temperatures }\end{array}$} \\
\hline & \multirow{2}{*}{\multicolumn{3}{|c|}{$\frac{\text { Bacteria cultured at } 37^{\circ} \mathrm{C}}{\text { Bacteria + Vero cells held at }}$}} & \multirow{2}{*}{\multicolumn{2}{|c|}{$\frac{\text { Bacteria cultured at } 22^{\circ} \mathrm{C}}{\text { Bacteria + Vero cells held at }}$}} \\
\hline & & & & & \\
\hline & $37^{\circ} \mathrm{C}$ & $22^{\circ} \mathrm{C}$ & $0^{\circ} \mathrm{C}$ & $37^{\circ} \mathrm{C}$ & $22^{\circ} \mathrm{C}$ \\
\hline S. typhimurium F98 & $5 \cdot 4$ & $5 \cdot 5$ & $3 \cdot 2$ & $4 \cdot 1$ & $4 \cdot 4$ \\
\hline S. hadar $1481 / 79$ & $5 \cdot 4$ & $5 \cdot 4$ & $3 \cdot 4$ & $4 \cdot 7$ & $4 \cdot 2$ \\
\hline S. virchow 961 & 5.8 & $5 \cdot 8$ & $3 \cdot 6$ & $4 \cdot 7$ & 4.9 \\
\hline S. heidelberg 17705 & $5 \cdot 8$ & $6 \cdot 1$ & $3 \cdot 5$ & $3 \cdot 7$ & $4 \cdot 6$ \\
\hline Sh.flexneri 59 & $3 \cdot 8$ & $3 \cdot 3$ & $1 \cdot 8$ & 0.7 & $1 \cdot 5$ \\
\hline
\end{tabular}

Table IV. The effect of metabolic and phagocytic inhibitors on Vero cell invasion

\begin{tabular}{|c|c|c|c|}
\hline \multirow[b]{2}{*}{ Organism } & \multirow[b]{2}{*}{ Chemical } & \multicolumn{2}{|c|}{$\log _{10} \mathrm{cfu} / \mathrm{ml}$} \\
\hline & & $\begin{array}{l}\text { in contact with } \\
\text { Vero cells }\end{array}$ & $\begin{array}{c}\text { in Vero cell } \\
\text { lysate }\end{array}$ \\
\hline S. typhimurium & $\begin{array}{l}\text { None } \\
\text { dinitrophenol } 0.01 \mathrm{mM} \\
\text { dinitrophenol } 0.1 \mathrm{mM} \\
\text { dinitrophenol } 1 \mathrm{mM} \\
\text { dinitrophenol } 2 \mathrm{mM}\end{array}$ & $\begin{array}{l}7 \cdot 3 \\
7 \cdot 0(-55)^{*} \\
7 \cdot 1(-34) \\
6 \cdot 6(-80) \\
6 \cdot 5(-85)\end{array}$ & $\begin{array}{l}5 \cdot 1 \\
4 \cdot 9(-34)^{*} \\
4 \cdot 9(-33) \\
4 \cdot 5(-75) \\
3 \cdot 8(-96)\end{array}$ \\
\hline S. typhimurium & $\begin{array}{l}\text { None } \\
\text { iodoacetic acid } 0.01 \mathrm{~mm} \\
\text { iodoacetic acid } 0.1 \mathrm{~mm} \\
\text { iodoacetic acid } 0.2 \mathrm{mM} \\
\text { cytochalasin B } 0.1 \mu \mathrm{g} / \mathrm{ml} \\
\text { cytochalasin B } 1 \mu \mathrm{g} / \mathrm{ml} \\
\text { cytochalasin B } 2 \mu \mathrm{g} / \mathrm{ml} \\
\text { cytochalasin B } 4 \mu \mathrm{g} / \mathrm{ml} \\
\text { cytochalasin B } 8 \mu \mathrm{g} / \mathrm{ml}\end{array}$ & $\begin{array}{l}7 \cdot 4 \\
7 \cdot 4(+3) \\
7 \cdot 2(-35) \\
7 \cdot 3(-31) \\
7 \cdot 4(-9) \\
7 \cdot 5(+9) \\
7 \cdot 6(+32) \\
7 \cdot 2(-35) \\
7 \cdot 6(+27)\end{array}$ & $\begin{array}{l}4 \cdot 9 \\
4 \cdot 7(-30) \\
4 \cdot 4(-66) \\
4 \cdot 0(-86) \\
4 \cdot 4(-63) \\
4 \cdot 7(-38) \\
4 \cdot 2(-79) \\
4 \cdot 6(-49) \\
4 \cdot 4(-68)\end{array}$ \\
\hline S. typhimurium & $\left\{\begin{array}{l}\text { None } \\
\text { cholera toxin } 1 \mu \mathrm{g} / \mathrm{ml} \\
\text { cholera toxin } 10 \mu \mathrm{g} / \mathrm{ml} \\
\text { cholera toxin } 100 \mu \mathrm{g} / \mathrm{ml}\end{array}\right.$ & $\begin{array}{l}6 \cdot 8 \\
7 \cdot 2(+62) \\
7 \cdot 1(+51) \\
7 \cdot 2(+65)\end{array}$ & $\begin{array}{l}3 \cdot 8 \\
4 \cdot 6(+85) \\
4 \cdot 6(+85) \\
3 \cdot 9(+13)\end{array}$ \\
\hline Sh.flexneri & $\left\{\begin{array}{l}\text { None } \\
\text { dinitrophenol } 2 \mathrm{mM} \\
\text { iodoacetic acid } 0.2 \mathrm{mM} \\
\text { cytochalasin B } 8 \mu \mathrm{g} / \mathrm{ml}\end{array}\right.$ & $\begin{array}{l}6 \cdot 9 \\
5 \cdot 5(-95) \\
6 \cdot 2(-80) \\
6 \cdot 6(-44)\end{array}$ & $\begin{array}{l}2.9 \\
1.5(-98) \\
0 \cdot 7(-99 \cdot 5) \\
0.7(-99 \cdot 5)\end{array}$ \\
\hline & $\begin{array}{l}\text { None } \\
\text { cholera toxin } 100 \mu \mathrm{g} / \mathrm{ml}\end{array}$ & $\begin{array}{l}6 \cdot 8 \\
6 \cdot 8(-11)\end{array}$ & $\begin{array}{l}3 \cdot 1 \\
2 \cdot 6(-71)\end{array}$ \\
\hline
\end{tabular}

*Percentage change in viable count compared to chemical free control.

Cytochalasin B and iodoacetic acid produced smaller and variable reductions in invasion by $S$. typhimurium, but invasion of Sh. flexneri was reduced by $>99 \%$. Cholera toxin apparently caused small increases in the counts of $S$. typhimurium in contact with the cells as well as in the cell lysate; invasiveness of Sh. flexneri was slightly reduced.
The number of $S$. typhimurium F98 recovered from the cell lysate always exceeded $10^{3 \cdot 8} \mathrm{cfu}$.

\section{Vero-cell invasion by Salmonella mutants}

The results of assessing the invasiveness of mutants of $S$. gallinarum $9, S$. pullorum 3, $S$. 
typhimurium F98 and $S$. infantis $1326 / 28$ are shown in table V. For this experiment, the inoculum of $S$. pullorum was increased by a factor of 10. Mutants of $S$. gallinarum and $S$. pullorum which had been cured of their virulence-associated plasmids were as invasive as the parent strain. A fivefold reduction was observed in the invasiveness of a variant of $S$. typhimurium cured of a virulence plasmid. The rough cell-wall mutants of $S$. gallinarum, $S$. typhimurium and $S$. infantis and a mutant of $S$. infantis which did not produce mannose-sensitive haemagglutinins (MSHA) were as invasive as the parent strains. Smooth non-motile mutants of $S$. typhimurium and $S$. infantis were examined. The $S$. infantis also possessed MSHA. The invasiveness of the $S$. typhimurium mutant was reduced 20 -fold and that of the $S$. infantis mutant 200 -fold. An additional mutant of $S$. infantis which was smooth, motile and possessed MSHA was created by NTG treatment. The invasiveness of this mutant was reduced almost 100-fold.

\section{Discussion}

These results show that bacterial invasiveness can be quantified readily in vitro in Vero, HeLa, bovine and chicken kidney, chick embryo fibroblast and human intestinal cell monolayers. This extends previous findings with HeLa (Giannella et al., 1973; Kihlstrom and Edebo, 1976; Kihlstrom and Latkovic, 1978; Jones et al., 1981) and HEp-2 cells (Small et al., 1987).

Quantitative bacteriology with Vero cells was reproducible and was able to detect intermediate invasiveness in bacteria that appeared non-invasive by microscopy. Intermediate invasiveness is unlikely to be due to incomplete killing of extracellular bacteria since there was little difference in the kanamycin sensitivity of strains that exhibited varying abilities to invade.

Salmonella and Shigella were the most invasive genera. Some of the serotypes which produce systemic disease in a limited number of host species, such as $S$. gallinarum, $S$. pullorum, $S$. abortus-ovis and $S$. abortus-equi, appeared less invasive than others. The reason for this is unclear. Some strains of $E$. coli and Citrobacter were moderately invasive, but there was no association between the degree of invasiveness of the $E$. coli strains and the disease or host of origin. None of the $E$. coli strains studied were of the enteroinvasive type (Small et al., 1987). Citrobacter strains can produce systemic disease in man (Holmes and Gross, 1983) and it would be interesting to assess the rôle of invasiveness in the pathogenicity of this genus.

Invasion by $S$. typhimurium was detectable even when the number present was as low as $10^{3}-10^{4} \mathrm{cfu} /$ $\mathrm{ml}$. Invasion was very rapid, but this may reflect rapid, irreversible attachment followed by incomplete killing by kanamycin during the phase of uptake. This suggests that irreversible attachment may occur more quickly than the 5 min suggested by Jones $e t$ al. (1981). The rate of increase in the numbers of intracellular bacteria reached a maximum after $1-2 \mathrm{~h}$ contact time. Since a relatively small percentage of Vero cells contained bacteria, this suggests that monolayers may be heterogenous in terms of susceptibility. The minimal intracellular multiplication of the $S$. typhimurium strain is not surprising since multiplication in mucosal cells is

Table V. Vero cell invasion by Salmonella mutants

\begin{tabular}{|c|c|c|c|c|}
\hline \multirow[b]{2}{*}{ Strain characteristic } & \multicolumn{4}{|c|}{$\log _{10}$ viable count $/ \mathrm{ml}$ of Vero-cell lysate } \\
\hline & S. gallinarum 9 & S. pullorum 3 & $\begin{array}{l}\text { S. typhimurium } \\
\text { F98 }\end{array}$ & S. infantis $1326 / 28$ \\
\hline $\begin{array}{l}\text { Parent } \\
\text { Rough cell-wall* } \\
\text { Non-motile } \dagger \\
\text { Non-haemagglutinating } \dagger \\
\text { Virulence plasmid-less } \\
\text { NTG-treated } \ddagger\end{array}$ & $\begin{array}{l}3 \cdot 0 \\
3 \cdot 4 \\
\ldots \\
3 \cdot 2 \\
\text { NT }\end{array}$ & $\begin{array}{l}3 \cdot 2 \\
\text { NT } \\
\ldots \\
\cdots \\
3 \cdot 3 \\
\text { NT }\end{array}$ & $\begin{array}{l}5 \cdot 7 \\
5 \cdot 7 \\
4 \cdot 4 \\
\cdots \\
5 \cdot 0 \\
\text { NT }\end{array}$ & $\begin{array}{l}4 \cdot 7 \\
4 \cdot 5 \\
2 \cdot 2 \\
4 \cdot 3 \\
\ldots \\
2 \cdot 6\end{array}$ \\
\hline $\begin{array}{l}\mathrm{NT}=\text { Not tested. } \\
\ldots=\text { Not relevant. } \\
{ }^{*} \text { Induced by bacteriophag } \\
+ \text { Induced by NTG treatme }\end{array}$ & & & . & \\
\hline
\end{tabular}


not a characteristic of the pathogenicity of Salmonella spp.

Live bacteria were required for invasion. Hale $e t$ al. (1979) also found that metabolically active cells of Sh. flexneri $2 \mathrm{a}$ were required to stimulate endocytosis by Henle intestinal epithelial cells. The present finding, that lowering the ambient temperature of the Vero cells to $0^{\circ} \mathrm{C}$ considerably reduced invasion by Salmonella spp. and Sh. flexneri, supports the contention that eukaryotic cellular activity contributes considerably to invasion by both genera. At $0^{\circ} \mathrm{C}$ Salmonella spp. were more invasive than Sh. flexneri, suggesting that the bacterial contribution to invasion by Salmonella spp. may be greater. In support of this, relatively small reductions in $S$. typhimurium invasiveness were induced by cholera toxin and cytochalasin B, chemicals which directly affect cell phagocytosis (Cox and Karnovsky, 1973; Axline and Reven, 1974) and by iodoacetic acid and dinitrophenol, inhibitors of cell metabolism.

A difference between Shigella and Salmonella was also seen when the bacteria were grown at a reduced temperature. Growth at $22^{\circ} \mathrm{C}$ profoundly reduced the invasiveness of Sh. flexneri 59 as reported previously (Maurelli et al., 1984), while having no effect on the invasiveness of four Salmonella strains. This effect has also been reported previously (Small et al., 1987). It is likely, therefore, that the microbial determinants of invasion in these two genera are very different.

The involvement of MSHA (type-1 pili) in invasion by Salmonella spp. is unlikely because Dmannose did not reduce the invasion by 11 Salmonella strains, and a mutant of $S$. infantis which did not produce MSHA was, nonetheless, invasive.

\section{REFERENCES}

Axline S G, Reaven E P 1974 Inhibition of phagocytosis and plasma membrane mobility of the cultivated macrophage by cytochalasin $\mathbf{B}$. Role of subplasmalemmal microfilaments. Journal of Cell Biology 62: 647-659.

Barrow P A 1986 Bacteriophages mediating somatic antigenic conversion in Salmonella cholerae-suis; their isolation from sewage and other Salmonella serotypes possessing the somatic 6 antigen. Journal of General Microbiology 132: 835-837.

Barrow P A, Huggins M B, Lovell M A, Simpson J M $1987 a$ Observations on the pathogenesis of experimental Salmonella typhimurium infection in chickens. Research in Veterinary Science 42: 194-199.

Barrow P A, Simpson J M, Lovell M A, Binns M M $1987 b$ Contribution of Salmonella gallinarum large plasmid toward virulence in fowl typhoid. Infection and Immunity 55: 388382.

Barrow P A, Lovell M A 1988 The association between a large
Rough strains were as invasive as the smooth parent strains. This is in contrast to the findings of Kihlstrom and Edebo (1976) who found that their rough strains were more adherent and thus more invasive. The involvement of flagellar antigens is less clear. Jones et al. (1981) suggested that motility facilitates initial contact with cells. Carsiotis et al. (1984) also found that the possession of flagella was a virulence characteristic for $S$. typhimurium. In our study, non-motile strains of $S$. typhimurium and $S$. infantis were less invasive, suggesting that motility might indeed contribute to invasion. An additional unidentified factor was present in $S$. infantis which could be eliminated by NTG.

The virulence-associated plasmids of $S$. typhimurium, S. gallinarum and $S$. pullorum were not essential to Vero-cell invasion by these strains. This agrees with the in-vivo findings of Pardon et al. (1986) and Gulig and Curtiss (1987). However, Barrow et al. (1987b), found that the virulence plasmid of $S$. gallinarum contributed to invasion in older chickens but not in newly-hatched birds, perhaps because the complex gut flora of older birds hindered colonisation by the plasmid-cured variant. Phagocytic cells have also been demonstrated engulfing bacteria in the intestinal lumen (Popiel and Turnbull, 1985). It is likely, therefore, that invasion in vivo is multifactorial. Use of a cellculture system in vitro should simplify experimental work on invasion by eliminating the need to consider colonisation and by eliminating the involvement of phagocytic cells.

We thank Mrs S. Brown and Mrs M. Kirkby for providing the cell cultures and Miss H. Vickery for preparing the typescript.

molecular weight plasmid and virulence in Salmonella pullorum. Journal of General Microbiology 134: 2307-2316.

Barrow P A, Simpson J M, Lovell M A 1988 Intestinal colonization in the chicken by food-poisoning Salmonella serotypes: microbial characteristics associated with faecal excretion. Avian Pathology 17: 571-588.

Buxton A 1957 Salmonellosis in animals: a review. Commonwealth Agricultural Bureaux, Farnham Royal, England.

Carsiotis M, Weinstein D L, Karch H, Holder I A, O'Brien A D 1984 Flagella of Salmonella typhimurium are a virulence factor in infected C57BL/6J mice. Infection and Immunity 46: 814-818.

Clarke R C, Gyles C L 1985 Virulence of wild and mutant strains of Salmonella typhimurium in the calf. In : Snoeyenbos $\mathrm{G} \mathbf{H}$ (ed) Proceedings of the International Symposium on Salmonella, New Orleans. American Association of Avian Pathologists, Philadelphia, p. 364.

Cox J P, Karnovsky M L 1973 The depression of phagocytosis by exogenous cyclic nucleotides, prostaglandins and theophylline. Journal of Cell Biology 59 : 480-490.

Day D W, Mandal B K, Morson B C 1978 The rectal biopsy 
appearances in Salmonella colitis. Histopathology 2: 117131.

Devenish J A, Schiemann D A 1981 HeLa cell infection by Yersinia enterocolitica: evidence for lack of intracellular multiplication and development of a new procedure for quantitative expression of infectivity. Infection and Immunity 32 : $48-55$.

Giannella R A 1975 Pathogenesis of Salmonella enteritis and diarrhoea. In: Schlessinger D (ed) Microbiology. American Society for Microbiology, Washington, D.C., pp 170-173.

Giannella R A, Washington O, Gemski P, Formal S B 1973 Invasion of HeLa cells by Salmonella typhimurium: a model for study of invasiveness of Salmonella. Journal of Infectious Diseases 128: 69-75.

Gulig P A, Curtiss R 1987 Plasmid-associated virulence of Salmonella typhimurium. Infection and Immunity 55: 28912901.

Hale T L, Morris R E, Bonventre P F 1979 Shigella infection of Henle intestinal epithelial cells: role of the host cell. Infection and Immunity 24: 887-894.

Hale T L, Sansonetti P J, Schad P A, Austin S, Formal S B 1983 Characterization of virulence plasmids and plasmid-associated outer membrane proteins in Shigella flexneri, Shigella sonnei and Escherichia coli. Infection and Immunity 40: 340350 .

Holmes B, Gross R J 1983 Coliform Bacteria; various other members of the Enterobacteriaceae. In: Parker M T (ed) Topley and Wilson's Principles of Bacteriology, Virology and Immunity, 7th edn, vol. 2 Edward Arnold, London, pp 285-309.

Jones G W, Richardson L A 1981 The attachment to, and invasion of, HeLa cells by Salmonella typhimurium: the contribution of mannose-sensitive and mannose-resistant haemagglutinating activities. Journal of General Microbiology 127: 361-370.

Jones G W, Richardson L A, Uhlman D 1981 The invasion of HeLa cells by Salmonella typhimurium: reversible and irreversible bacterial attachment and the role of bacterial motility. Journal of General Microbiology 127 : 351-360.

Jones G W, Rabert D K, Svinarich D M, Whitfield H J 1982 Association of adhesive, invasive and virulent phenotypes of Salmonella typhimurium with autonomous 60-Megadalton plasmids. Infection and Immunity 38: 476-486.

Kent T H, Formal S B, Labrec E H 1966 Salmonella gastroenteritis in Rhesus monkeys. Archives of Pathology 82: $272-279$.

Kihlstrom E, Edebo L 1976 Association of viable and inactivated Salmonella typhimurium $395 \mathrm{MS}$ and MR 10 with HeLa cells. Infection and Immunity 14: 851-857.

Kihlstrom E, Latkovic S 1978 Ultrastructural studies on the interaction between Salmonella typhimurium $395 \mathrm{MS}$ and HeLa cells. Infection and Immunity 22: 804-809.

Maurelli A, Blackmon B, Curtiss R 1984 Temperature-dependent expression of virulence genes in Shigella species. Infection and Immunity 43: 195-201.

Okamura N, Nagai T, Nakaya R, Kondo S, Murakami M, Hisatsune K $1983 \mathrm{HeLa}$ cell invasiveness and $\mathrm{O}$ antigen of Shigella flexneri as separate and prerequisite attributes of virulence to evoke keratoconjunctivitis in guinea pigs. Infection and Immunity 39: 505-513.
Pardon P, Popoff M Y, Coynault C, Marly J, Miras I 1986 Virulence associated plasmids of Salmonella serotype typhimurium in experimental murine infection. Annales de l'Institut Pasteur 137B : 47-60.

Peerbooms P G H, Verweij A M J J, MacLaren D M 1984 Vero cell invasiveness of Proteus mirabilis. Infection and Immunity 43: 1068-1071.

Peerbooms P G H, Verweij A M J J, MacLaren D M 1985 Uropathogenic properties of Proteus mirabilis and Proteus vulgaris. Journal of Medical Microbiology 19: 55-60.

Popiel I, Turnbull P C B 1985 Passage of Salmonella enteritidis and Salmonella thompson through chick ileocaecal mucosa. Infection and Immunity 47: 786-792.

Sansonetti P J, Hale T L, Dammin G J, Kapfer C, Collins H H, Formal S B 1983 Alterations in the pathogenicity of Escherichia coli $\mathrm{K} 12$ after transfer of plasmid and chromosomal genes from Shigella flexneri. Infection and Immunity 39: $1392-1402$.

Sansonetti P J, Kopecko D J, Formal S B 1982 Involvement of a plasmid in the invasive ability of Shigella flexneri. Infection and Immunity 35: 852-860.

Sansonetti P J, Ryter A, Clerc P, Maurelli A T, Mournier J 1986 Multiplication of Shigella flexneri within HeLa cells: lysis of the phagocytic vacuole and plasmid-mediated contact hemolysis. Infection and Immunity 51 : 461-469.

Small P L C, Isberg R P, Falkow S 1987 Comparison of the ability of enteroinvasive Escherichia coli, Salmonella typhimurium, Yersinia pseudotuberculosis and Yersinia enterocolitica to enter and replicate within HEp- 2 cells. Infection and Immunity 55: 1674-1679.

Smith H W 1955 Observations on experimental fowl typhoid. Journal of Comparative Pathology and Therapeutics 65: 3754.

Smith H W 1965 The immunization of mice, calves and pigs against Salmonella dublin and Salmonella cholerae-suis infection. Journal of Hygiene 63: 117-135.

Smith H W, Jones J E T 1967 Observations on experimental oral infection with Salmonella dublin in calves and Salmonella cholerae-suis in pigs. Journal of Pathology and Bacteriology 93 : 141-156.

Smith H W, Halls S 1968 The simultaneous oral administration of Salmonella dublin, $S$. typhimurium and $S$. choleraesuis to calves and other animals. Journal of Medical Microbiology 1: 203-209.

Tannock G W, Blumershine R V H, Savage D C 1975 Association of Salmonella typhimurium with, and its invasion of the ileal mucosa in mice. Infection and Immunity 11 : 365 370 .

Turnbull P C B, Richmond J E 1978 A model of Salmonella enteritis: the behaviour of Salmonella enteritidis in chick intestine studied by light and electron microscopy. British Journal of Experimental Pathology 59: 64-75.

Watanabe H, Nakamura A 1986 Identification of Shigella sonnei Form I plasmid genes necessary for cell invasion and their conservation among Shigella species and enteroinvasive Escherichia coli. Infection and Immunity 53: 352-358.

Watanabe H, Timmis K N 1984 A small plasmid in Shigella dysenteriae 1 specifies one or more functions essential for $\mathrm{O}$ antigen production and bacterial virulence. Infection and Immunity 43: 391-396. 